\title{
Experimental antegrade enema. Effects on water, electrolyte and acid-base balances with different solutions ${ }^{1}$
}

\author{
Enema anterógrado experimental. Equilíbrio hídrico eletrolítico e ácido-base em \\ coelhos submetidos a enema com diferentes soluções
}

\author{
Laura Helman², José Luiz Martins³, Djalma José Fagundes ${ }^{4}$, Edward Esteves ${ }^{5}$, Cirilo de Paula Lima ${ }^{6}$, Álisson de \\ Souza Costa ${ }^{7}$ \\ 1. Research performed at Pediatric Surgery and Operative Technique and Experimental Surgery Divisions, Federal University of São Paulo (UNIFESP), \\ São Paulo, Brazil. \\ 2. Consultant in Pediatric Surgery, Pediatric Department, Faculty of Medicine, Federal University of Uberlândia (FAMED-UFU), Minas Gerais, Brazil. \\ 3. Associate Professor, Division of Pediatric Surgery, Department of Surgery, UNIFESP, São Paulo, Brazil. \\ 4. Associate Professor, Department of Surgery, UNIFESP, São Paulo, Brazil. \\ 5. Assistant Professor, Pediatric Surgery and Urology, Federal University of Goiás, Brazil. \\ 6. Associate Professor, Faculty of Veterinary Medicine, FAMEV-UFU, Minas Gerais, Brazil. \\ 7. Graduate student, (FAMEV-UFU), Minas Gerais, Brazil.
}

\begin{abstract}
Purpose: To study the effects on the water, electrolyte, and acid-base balances in rabbits submitted to antegrade enema with different solutions through appendicostomy. Methods: Forty male New Zealand rabbits were submitted to appendicostomy, and distributed in 4 groups, according to the antegrade enema solution: PEG group, polyethylene glycol electrolyte solution ( $n=10)$; ISS group, isotonic saline solution $(n=10)$; GS group, glycerin solution ( $n=10)$; SPS group, sodium phosphate solution $(\mathrm{n}=10)$. After being weighed, arterial blood gas analysis, red blood count, creatinine and electrolytes were measured at 4 times: preoperatively (T1); day 6 postop, before enema (T2); 4h after enema (T3); and 24h after T3 (T4). Results: In PEG group occurred Na retention after 4h, causing alkalemia, sustained for $24 \mathrm{~h}$ with HCO3 retention. In ISS group occurred isotonic water retention and hyperchloremic acidosis after $4 \mathrm{~h}$, which was partially compensated in $24 \mathrm{~h}$. GS group showed metabolic acidosis after $4 \mathrm{~h}$, compensated in $24 \mathrm{~h}$. In SPS group occurred hypernatremic dehydration, metabolic acidosis in $4 \mathrm{~h}$, and hypokalemia, hypocalcemia, hypomagnesemia, and metabolic alkalosis with partially compensated dehydration in $24 \mathrm{~h}$. Conclusions: All solutions used in this study caused minor alterations on water, electrolyte or acid-base balances. The most intense ones were caused by hypertonic sodium phosphate solution (SPS) and isotonic saline solution (ISS) and the least by polyethyleneglycol electrolyte solution (PEG) and glycerin solution 12\% (GS). Key words: Enema. Appendix. Fecal Incontinence. Rabbits.
\end{abstract}

\section{RESUMO}

Objetivo: Estudar os efeitos no equilíbrio hídrico, eletrolítico e ácido-base, do enema anterógrado com diferentes soluções em coelhos através de apendicostomia. Métodos: 40 coelhos Nova Zelândia, machos, submetidos a apendicostomia, distribuídos em quatro grupos segundo a solução de enema: grupo PEG $(\mathrm{n}=10)$ solução de polietilenoglicol com eletrólitos; grupo SF $(n=10)$ solução fisiológica; grupo SG $(n=10)$ solução glicerinada; grupo FS $(n=10)$ solução de fosfato de sódio. Realizou-se pesagem, gasometria arterial, série vermelha, creatinina e ionograma, em quatro tempos: TI (pré-operatório); T2 (6o PO antes do enema); T3 (4h após enema); T4 (24h após T3). Resultados: No PEG ocorreu retenção de $\mathrm{Na}$ em 4h, com alcalemia por retenção de HCO3, mantida por 24h. No SF ocorreu retenção hídrica isotônica e acidose hiperclorêmica em $4 \mathrm{~h}$, resolvidos parcialmente com $24 \mathrm{~h}$. No SG ocorreu acidose metabólica hiperclorêmica em 4h, compensada com 24h. No FS ocorreu desidratação hipenatrêmica, acidose metabólica com ânion gap elevado em $4 \mathrm{~h}$, hipopotassemia, hipocalcemia, hipomagnesemia e alcalose metabólica com recuperação parcial da desidratação em 24h. Conclusões: Todas as soluções empregadas neste estudo causam alterações de pouca intensidade no equilíbrio hídrico, eletrolítico ou ácido-base. As mais intensas foram causadas pela solução de fosfato de sódio e solução fisiológica, e as menos intensas pela solução de polietilenoglicol com eletrólitos e solução glicerinada. Descritores: Enema. Apêndice. Incontinência Fecal. Coelhos. 


\section{Introduction}

In 1990, Malone, Ransley and Kiely ${ }^{1}$ described a new and simple procedure to manage fecal incontinence in children. The technique was quickly widespread and its applicability was extended to several causes of fecal incontinence and intractable intestinal obstipation, in adults and children, dramatically improving quality of life and social adjustment of many patients ${ }^{2}$. Since the antegrade enema procedure was designed, it has been difficult to establish an appropriate colonic irrigation protocol. It is usually developed based on an individual trial and error basis for each of the patients ${ }^{1}$. The solutions, their volumes and intervals between washouts are tested and modified whenever necessary in a process which usually takes, approximately, a month after operation, but which can take up to six months ${ }^{3}$. Metabolic iatrogenic complications of enema administration in children are not rare, but most of them are self-limited and have no clinical manifestations. Nevertheless, at least one fatality4 and other potentially seriuos complications have already been reported ${ }^{5,6,7}$. Other clinical manifestations such as nausea, dizziness, autonomic dysreflexia, cephalalgia and abdominal cramps are quite frequent and the reason why some patients gave up treatment $8,9,10,11,12$. Antegrade enema protocol through cecal access is a matter which still requires further investigation. Which solution is the most well-tolerated from the perspectives of water and electrolyte balance and renal function? What is the best enema regimen for patients suffering from intestinal dismotility or other pathologies? ${ }^{10}$ Such reflections suggest that a safer and more efficient enema protocol has not yet been designed ${ }^{12}$. In 1998, Esteves and Martins ${ }^{13}$ carried out an experimental study in rabbits comparing appendicostomies with and without cecal plication, and designed a new empirical model continent appendicostomy, laying some more groundwork for new experimental studies. Thus, this study aimed at shedding some light on antegrade enema effects on water, electrolyte and acid-base balances, caused by some frequently used enema solutions administered in rabbits through appendicostomy.

\section{Methods}

Forty male New Zealand rabbits, aged 60-70 days, weighing between 470 and 1000 grams (g) (mean weight $720 \mathrm{~g}$ ) took part in this study. They were kept in individual cages, in good hygiene conditions, with natural light and aeration; fed at will with rabbit feed and water during the whole pre and post-operation periods at the bioterium of the Faculty of Veterinarian Medicine, Federal University of Uberlândia (FAMEV-UFU). This study was approved by the Research Ethics Committee of the Federal University of São Paulo (UNIFESP). The animals were weighed and their blood sample taken through alternate punctures on right or left medial auricular artery at 4 times. Time T1 - before appendicostomy (before anesthesia). Time T2 - day 6 postop before antegrade enema. Time T3 - four hours after enema took place (four hours after T2) and time T4 - 24 hours after T3. For all arterial blood samples the following analyses were carried out: gasometry, red series, levels of creatinine, sodium $(\mathrm{Na})$, chloride $(\mathrm{Cl})$, calcium $(\mathrm{Ca})$, potassium $(\mathrm{K})$, phosphorus $(\mathrm{P})$ and magnesium $(\mathrm{Mg})$. General anesthesia was administered by means of a combination of ketamine $25 \mathrm{mg} / \mathrm{kg}$, xylazine $0.25 \mathrm{mg} / \mathrm{kg}$, midazolam $0.2 \mathrm{mg} / \mathrm{kg}$ and acepromazine $0.2 \mathrm{mg} / \mathrm{kg}$, via intramuscular in the femoral quadriceps. Then a one-dose preoperative prophylactic antibioticotherapy was administered by a combination of sulbactam and ampiciline $75 \mathrm{mg} / \mathrm{kg}$ in the lateral auricular vein and local anesthesia performed with $1 \mathrm{ml}$ bupivacaine with adrenaline at incision site. All animals were submitted to a continent appendicostomy by means of laparostomy through a longitudinal medial incision, then cecum and appendix were drawn out; and appendix distal vases, ligated and sectioned. An intussusception of the appendix base into the cecum was followed by a round cecal plication, which was fixed by independent seromuscular stitches, the appendix distal end removed in its blind end and the appendicostomy was fixed through a lateral opening on the right side of the incision. On day 6 postop, the animals were randomly distributed in four groups of ten; according to the antegrade enema solution type they were given.

-PEGGroup-polyethyleneglycolelectrolytesolution $(\mathrm{n}=10)$ - ISS group - isotonic saline solution $(n=10)$

- GS group -glycerin solution $12 \%(n=10)$

- SPS group -hypertonic sodium phosphate solution $(\mathrm{n}=10)$

The solutions were heated to $39^{\circ}$ Celsius and the antegrade enema was administered through a $3 \mathrm{~mm}$ silicon catheter by an infusion bomb, at a constant rate of $20 \mathrm{ml}$ per minute. The enema volume for each solution was previously set by pilot-study, in which, after designing a continent appendicostomy, each solution was tested separately, in different volumes, in order to determine the highest volume that, when administered into the cecum through the catheter, would provoke intense and liquid diarrhea, which would be well tolerated and not lead to animal death. For the PEG group the content of each envelope of $54.8 \mathrm{~g}$ was: $1.1785 \mathrm{~g}$ sodium chloride $(\mathrm{NaCl}) ; 0.5992 \mathrm{~g}$ potassium chloride $(\mathrm{kCl})$; $1.3383 \mathrm{~g}$ sodium bicarbonate (NaHCO3); 4.5442g sodium sulphate (Na2SO4) and $47.1398 \mathrm{~g}$ polyethylene glycol 4000. Polyethylene glycol electrolyte solution powder was diluted into 11 distilled water and a $300 \mathrm{ml}$ antegrade enema volume administered to each animal. In ISS group each $100 \mathrm{ml}$ of solution was composed of $0.9 \mathrm{~g} \mathrm{NaCl}$. A $200 \mathrm{ml}$ isotonic saline solution at $0.9 \%$ was administered to each animal. In GS group (at 12\%) each $100 \mathrm{ml}$ of solution had $12 \mathrm{~g}$ glycerin, and a $60 \mathrm{ml}$ volume was administered to each animal. In the SPS group the $5 \mathrm{ml}$ solution was composed of $2.4 \mathrm{~g}$ monobasic sodium phosphate $(\mathrm{NaH} 2 \mathrm{PO} 4)$ and $0.9 \mathrm{~g}$ dibasic sodium phosphate (NaHPO4). A $6 \mathrm{ml}$ volume was 
used for each enema. After the enema, it was observed a great quantity of fecal evacuation of a viscous consistence, semi-fluid and, at last, liquid and clear in all animals. The statistical study was carried out with variance analysis for non-independent groups. Whenever the analysis showed a significant difference, the Tukey test was performed. Likewise when variance analysis by Friedman's test showed a significant difference, it was followed by the multiple comparisons test and variance analysis by Kruskal-Wallis test. The level of significance was set as $(\mathrm{P})$ equal or lower than 0.05 .

\section{Results}

Tables 1, 2, 3 and 4 show the mean values of weight and hematological findings for PEG, ISS, GS and SPG respectively at times $\mathrm{T} 1$ - pre-operation, T2 - day 6 postop, immediately before enema, T3 - 4 hours after enema and T4 - 24 hours after T3. Blood samples values at T1 were set as normal for each group, since the rabbits were healthy and had not been submitted to any procedure. The animal weight at T1 showed no statistical difference among the groups which pointed to a homogeneousness of the sample in relation to the animals' age and weight. At time T2, the rabbits presented a non-significant decrease in hematocrit, attributed to the blood loss during operation, alike to all four groups. At T2 it was also observed for all groups compensated metabolic acidosis due to the operation.

TABLE 1 - Results for PEG group rabbits

\begin{tabular}{|c|c|c|c|c|c|}
\hline & T1 & $\mathbf{T 2}$ & T3 & T4 & Significance and $P$ value \\
\hline Weight & 694 & 679 & 728 & 722 & NS* \\
\hline Hematocrit & 36.6 & 31.5 & 26.3 & 24.1 & $\mathrm{~T} 1>\mathrm{T} 3$ and $\mathrm{T} 4 ; \mathrm{T} 2>\mathrm{T} 4(\mathrm{P}=0.000)$ \\
\hline $\mathrm{Na}$ & 159.4 & 142.9 & 153.5 & 150.2 & $\mathrm{~T} 1>\mathrm{T} 2, \mathrm{~T} 3$ and $\mathrm{T} 4 ; \mathrm{T} 2<\mathrm{T} 3$ e $\mathrm{T} 4(\mathrm{P}=0.000)$ \\
\hline $\mathrm{Cl}$ & 91.5 & 89.0 & 88.2 & 84.3 & NS* \\
\hline $\mathrm{HCO}_{3}$ & 19.4 & 18.9 & 20.1 & 24.7 & $\mathrm{~T} 4>\mathrm{T} 1, \mathrm{~T} 2$ and $\mathrm{T} 3(\mathrm{P}=0.004)$ \\
\hline $\mathrm{paCO}_{2}$ & 35.7 & 32.1 & 35.4 & 35.5 & NS* \\
\hline $\mathrm{pH}$ & 7.336 & 7.386 & 7.377 & 7.466 & $\mathrm{~T} 1<\mathrm{T} 4(\mathrm{P}=0.009)$ \\
\hline $\mathrm{BE}$ & -5.8 & -2.6 & -4.2 & +1.4 & $\mathrm{~T} 1$ and $\mathrm{T} 3<\mathrm{T} 4(\mathrm{P}=0.019)$ \\
\hline $\mathrm{K}$ & 6.5 & 5.6 & 5.0 & 5.4 & $\mathrm{~T} 1>\mathrm{T} 2, \mathrm{~T} 3$ and $\mathrm{T} 4(\mathrm{P}=0.007)$ \\
\hline $\mathrm{paO}_{2}$ & 65.0 & 77.0 & 65.0 & 75.0 & NS* \\
\hline creatinine & 0.50 & 0.45 & 0.39 & 0.32 & $\mathrm{~T} 1>\mathrm{T} 3$ and $\mathrm{T} 4 ; \mathrm{T} 2$ and $\mathrm{T} 3>\mathrm{T} 4(\mathrm{P}=0.000)$ \\
\hline $\mathrm{Ca}$ & 10.7 & 12.5 & 10.7 & 11.7 & NS* \\
\hline $\mathrm{P}$ & 8.58 & 6.38 & 7.04 & 5.22 & $\mathrm{~T} 1>\mathrm{T} 2, \mathrm{~T} 3$ and $\mathrm{T} 4 ; \mathrm{T} 3>\mathrm{T} 4(\mathrm{P}=0.000)$ \\
\hline $\mathrm{Mg}$ & 1.71 & 1.64 & 1.36 & 1.35 & $\mathrm{~T} 1>\mathrm{T} 3$ and $\mathrm{T} 4 ; \mathrm{T} 2>\mathrm{T} 4(\mathrm{P}=0.002)$ \\
\hline
\end{tabular}

Weight in grams; Hematocrit in \%; $\mathrm{Na}$ (sodium) in $\mathrm{mEq} / \mathrm{l} ; \mathrm{Na}$ sodium in $\mathrm{mEq} / \mathrm{l} ; \mathrm{Cl}$ (chloride) in $\mathrm{mEq} / \mathrm{l} ; \mathrm{HCO}_{3}$ (bicarbotate) in $\mathrm{mmol} / \mathrm{l} ; \mathrm{paCO}_{2}$ (partial pressure of carbon dioxide) in mmHg; BE (base excess) in mmol/l; $\mathrm{K}$ (potassium) in $\mathrm{mEq} / \mathrm{l}$; creatinine in $\mathrm{mg} / \mathrm{dl}$; $\mathrm{Ca}$ (calcium) in $\mathrm{mg} / \mathrm{dl}$; $\mathrm{P}$ (phosphorus) in $\mathrm{mg} / \mathrm{dl} ; \mathrm{Mg}$ (magnesium) in $\mathrm{mg} / \mathrm{dl}$.

* NS: non significant

TABLE 2 - Results for ISS group rabbits

\begin{tabular}{|c|c|c|c|c|c|}
\hline & T1 & $\mathbf{T 2}$ & T3 & T4 & Significance and $P$ value \\
\hline Weight & 681 & 666 & 746 & 739 & $\mathrm{~T} 3$ andT $4>\mathrm{T} 1$ and $\mathrm{T} 2(\mathrm{P}=0.003)$ \\
\hline Hematocrit & 36.1 & 30.8 & 25.8 & 24.0 & $\mathrm{~T} 1>\mathrm{T} 3$ and $\mathrm{T} 4 ; \mathrm{T} 2>\mathrm{T} 4(\mathrm{P}=0.000)$ \\
\hline $\mathrm{Na}$ & 156.0 & 149.5 & 149.2 & 147.6 & NS* \\
\hline $\mathrm{Cl}$ & 93.7 & 85.3 & 93.8 & 85.6 & $\mathrm{~T} 1$ andT3 $>\mathrm{T} 2$ andT4 $(\mathrm{P}=0.000)$ \\
\hline $\mathrm{HCO}_{3}$ & 20.0 & 19.6 & 16.9 & 22.0 & $\mathrm{~T} 3<\mathrm{T} 2$ and $\mathrm{T} 4(\mathrm{P}=0.025)$ \\
\hline $\mathrm{paCO}_{2}$ & 36.8 & 32.4 & 35.0 & 33.2 & NS* \\
\hline $\mathrm{pH}$ & 7.336 & 7.393 & 7.289 & 7.430 & $\mathrm{~T} 3<\mathrm{T} 4(\mathrm{P}=0.003)$ \\
\hline $\mathrm{BE}$ & -5.6 & -4.2 & -8.8 & -1.5 & $\mathrm{~T} 3<\mathrm{T} 4(\mathrm{P}=0.011)$ \\
\hline $\mathrm{K}$ & 6.3 & 5.4 & 5.6 & 5.2 & $\mathrm{~T} 1>\mathrm{T} 2$ and $\mathrm{T} 4(\mathrm{P}=0.017)$ \\
\hline $\mathrm{paO}_{2}$ & 62.4 & 67.0 & 64.7 & 74.2 & NS* \\
\hline creatinine & 0.46 & 0.44 & 0.38 & 0.33 & $\mathrm{~T} 4<\mathrm{T} 1$ and $\mathrm{T} 2(\mathrm{P}=0.02)$ \\
\hline $\mathrm{Ca}$ & 12.2 & 12.0 & 10.2 & 13.1 & $\mathrm{~T} 3<\mathrm{T} 1$ and $\mathrm{T} 4(\mathrm{P}=0.004)$ \\
\hline $\mathrm{P}$ & 7.87 & 6.49 & 6.56 & 5.27 & $\mathrm{~T} 1>\mathrm{T} 2, \mathrm{~T} 3, \mathrm{~T} 4 ; \mathrm{T} 2$ and $\mathrm{T} 3>\mathrm{T} 4(\mathrm{P}=0.000)$ \\
\hline $\mathrm{Mg}$ & 1.70 & 1.51 & 1.34 & 1.46 & $\mathrm{~T} 3<\mathrm{T} 1$ and $\mathrm{T} 2(\mathrm{P}=0.007)$ \\
\hline
\end{tabular}

Weight in grams; Hematocrit in \%; $\mathrm{Na}$ (sodium) in $\mathrm{mEq} / \mathrm{l} ; \mathrm{Na}$ sodium in $\mathrm{mEq} / \mathrm{l} ; \mathrm{Cl}$ (chloride) in $\mathrm{mEq} / \mathrm{l} ; \mathrm{HCO}_{3}$ (bicarbotate) in mmol/l; paCO (partial pressure of carbon dioxide) in mmHg; $\mathrm{BE}$ (base excess) in mmol/1; $\mathrm{K}$ (potassium) in $\mathrm{mEq} / \mathrm{l}$; creatinine in $\mathrm{mg} / \mathrm{dl}$; $\mathrm{Ca}$ (calcium) in $\mathrm{mg} / \mathrm{dl} ; \mathrm{P}$ (phosphorus) in $\mathrm{mg} / \mathrm{dl} ; \mathrm{Mg}$ (magnesium) in $\mathrm{mg} / \mathrm{dl}$.

* NS: non significant 
TABLE 3 - Results for GS group rabbits

\begin{tabular}{|c|c|c|c|c|c|}
\hline & T1 & $\mathbf{T 2}$ & T3 & T4 & Significance and $P$ value \\
\hline Weight & 756 & 745 & 717 & 730 & NS* \\
\hline Hematocrit & 36.8 & 30.8 & 30.7 & 26.5 & $\mathrm{~T} 1>\mathrm{T} 3$ andT4 $(\mathrm{P}=0.000)$ \\
\hline $\mathrm{Na}$ & 154.9 & 151.7 & 155.4 & 140.9 & $\mathrm{~T} 4<\mathrm{T} 1, \mathrm{~T} 2$ andT3 $(\mathrm{P}=0.025)$ \\
\hline $\mathrm{Cl}$ & 87.4 & 85.0 & 97.6 & 82.6 & $\mathrm{~T} 3>\mathrm{T} 1, \mathrm{~T} 2$ andT4 $(\mathrm{P}=0.000)$ \\
\hline $\mathrm{HCO}_{3}$ & 21.9 & 17.2 & 11.9 & 24.4 & $\mathrm{~T} 1$ andT4 $>\mathrm{T} 2$ andT3; T2 $>\mathrm{T} 3(\mathrm{P}=0.000)$ \\
\hline $\mathrm{paCO}_{2}$ & 38.1 & 31.0 & 26.9 & 34.0 & $\mathrm{~T} 1>\mathrm{T} 2$ andT $3 ; \mathrm{T} 3<\mathrm{T} 4(\mathrm{P}=0.00)$ \\
\hline $\mathrm{pH}$ & 7.370 & 7.355 & 7.248 & 7.472 & $\mathrm{~T} 2$ and $\mathrm{T} 3<\mathrm{T} 4(\mathrm{P}=0.000)$ \\
\hline $\mathrm{BE}$ & -2.1 & -6.9 & -13.6 & +1.4 & $\mathrm{~T} 1>\mathrm{T} 3 ; \mathrm{T} 2$ andT $3<\mathrm{T} 4(\mathrm{P}=0.000)$ \\
\hline K & 6.2 & 5.7 & 4.9 & 6.1 & $\mathrm{~T} 3<\mathrm{T} 1, \mathrm{~T} 2$ andT4 $(\mathrm{P}=0.002)$ \\
\hline $\mathrm{paO}_{2}$ & 59.9 & 74.2 & 82.0 & 77.7 & NS* \\
\hline creatinine & 0.48 & 0.49 & 0.61 & 0.38 & NS* \\
\hline $\mathrm{Ca}$ & 12.3 & 9.6 & 10.5 & 12.9 & $\mathrm{~T} 2<\mathrm{T} 1$ andT4; $\mathrm{T} 4>\mathrm{T} 3(\mathrm{P}=0.002)$ \\
\hline $\mathrm{P}$ & 7.88 & 7.44 & 8.10 & 5.46 & $\mathrm{~T} 4<\mathrm{T} 1, \mathrm{~T} 2$ andT3 $(\mathrm{P}=0.000)$ \\
\hline $\mathrm{Mg}$ & 1.60 & 1.51 & 1.61 & 1.31 & $\mathrm{~T} 4<\mathrm{T} 1, \mathrm{~T} 2$ andT3 $(\mathrm{P}=0.000)$ \\
\hline
\end{tabular}

Weight in grams; Hematocrit in \%; $\mathrm{Na}$ (sodium) in $\mathrm{mEq} / \mathrm{l} ; \mathrm{Na}$ sodium in $\mathrm{mEq} / \mathrm{l} ; \mathrm{Cl}$ (chloride) in $\mathrm{mEq} / \mathrm{l} ; \mathrm{HCO}_{3}$ (bicarbotate) in mmol/1; paCO 2 (partial pressure of carbon dioxide) in mmHg; $\mathrm{BE}$ (base excess) in mmol/l; $\mathrm{K}$ (potassium) in $\mathrm{mEq} / \mathrm{l}$; creatinine in $\mathrm{mg} / \mathrm{dl}$; $\mathrm{Ca}$ (calcium) in $\mathrm{mg} / \mathrm{dl}$; $\mathrm{P}$ (phosphorus) in $\mathrm{mg} / \mathrm{dl} ; \mathrm{Mg}$ (magnesium) in $\mathrm{mg} / \mathrm{dl}$.

* NS: non significant

TABLE 4 - Results for ISS group rabbits

\begin{tabular}{|c|c|c|c|c|c|}
\hline & $\mathbf{T 1}$ & $\mathbf{T 2}$ & T3 & T4 & Significance and $P$ value \\
\hline Weight & 750 & 817 & 719 & 756 & $\mathrm{~T} 2>\mathrm{T} 1, \mathrm{~T} 3$ andT4; $\mathrm{T} 4>\mathrm{T} 3(\mathrm{P}=0.007)$ \\
\hline Hematocrit & 37.0 & 34.0 & 32.4 & 29.8 & $\mathrm{~T} 1>\mathrm{T} 4(\mathrm{P}=0.003)$ \\
\hline $\mathrm{Na}$ & 152.9 & 145.6 & 167.0 & 140.9 & $\mathrm{~T} 1>\mathrm{T} 4 ; \mathrm{T} 3>\mathrm{T} 2$ andT4 $(\mathrm{P}=0.000)$ \\
\hline $\mathrm{Cl}$ & 90.4 & 85.4 & 96.8 & 82.5 & $\mathrm{~T} 3>\mathrm{T} 2$ andT $4(\mathrm{P}=0.001)$ \\
\hline $\mathrm{HCO}_{3}$ & 22.3 & 19.2 & 13.2 & 25.8 & $\mathrm{~T} 1$ andT4 $>\mathrm{T} 2$ andT3; $\mathrm{T} 2>\mathrm{T} 3(\mathrm{P}=0.000)$ \\
\hline $\mathrm{paCO}_{2}$ & 38.4 & 33.8 & 28.0 & 35.8 & $\mathrm{~T} 1$ andT4 $>\mathrm{T} 3(\mathrm{P}=0.004)$ \\
\hline $\mathrm{pH}^{2}$ & 7.382 & 7.372 & 7.291 & 7.467 & $\mathrm{~T} 3<\mathrm{T} 4(\mathrm{P}=0.001)$ \\
\hline $\mathrm{BE}$ & -2.3 & -5.0 & -11.6 & +2.4 & $\mathrm{~T} 3<\mathrm{T} 1, \mathrm{~T} 2$ andT4 $(\mathrm{P}=0.000)$ \\
\hline K & 6.3 & 5.4 & 3.9 & 4.7 & $\mathrm{~T} 1$ andT $2>\mathrm{T} 3$ andT4 $(\mathrm{P}=0.000)$ \\
\hline $\mathrm{paO}_{2}$ & 64.9 & 73.6 & 85.2 & 77.2 & NS* \\
\hline creatinine & 0.54 & 0.41 & 0.59 & 0.43 & $\mathrm{~T} 1$ andT $3>\mathrm{T} 2$ andT4 $(\mathrm{P}=0.000)$ \\
\hline $\mathrm{Ca}$ & 13.3 & 8.4 & 7.1 & 10.5 & $\mathrm{~T} 1$ andT4 $>\mathrm{T} 2$ andT3 $(\mathrm{P}=0.000)$ \\
\hline $\mathrm{P}$ & 7.54 & 7.24 & 8.07 & 6.10 & NS* \\
\hline $\mathrm{Mg}$ & 1.73 & 1.64 & 1.14 & 1.09 & $\mathrm{~T} 1$ andT2 $>\mathrm{T} 3$ andT4 $(\mathrm{P}=0.000)$ \\
\hline
\end{tabular}

Weight in grams; Hematocrit in \%; $\mathrm{Na}$ (sodium) in $\mathrm{mEq} / \mathrm{l} ; \mathrm{Na}$ sodium in $\mathrm{mEq} / \mathrm{l} ; \mathrm{Cl}$ (chloride) in $\mathrm{mEq} / \mathrm{l} ; \mathrm{HCO}_{3}$ (bicarbotate) in mmol/l; $\mathrm{paCO}$ ( pressure of carbon dioxide) in $\mathrm{mmHg}$; $\mathrm{BE}$ (base excess) in mmol/1; $\mathrm{K}$ (potassium) in $\mathrm{mEq} / \mathrm{l}$; creatinine in $\mathrm{mg} / \mathrm{dl} ; \mathrm{Ca}$ (calcium) in $\mathrm{mg} / \mathrm{dl} ; \mathrm{P}$ (phosphorus) in $\mathrm{mg} / \mathrm{dl} ; \mathrm{Mg}$ (magnesium) in $\mathrm{mg} / \mathrm{dl}$.

- NS: non significant

\section{PEG Group}

At time T3, the enema caused a non significant weight increase, significant $\mathrm{Na}$ retention in relation to $\mathrm{T} 2$ and alkalemia sustained during 24 hours, by a significant $\mathrm{HCO} 3$ and Na retention at time $\mathrm{T} 4$, in relation to $\mathrm{T} 2$.

\section{ISS Group}

At time T3, the enema provoked an isotonic liquid retention with weight increase and a significant hemodilution and sustained natremia. Moderate acidemia with metabolic acidosis, hyperchloremia, was probably due to intestinal absorption of liquid and chloride. At time T4 there was a partial compensation of acidosis and normalization of $\mathrm{pH}$ in relation to time $\mathrm{T} 2$, at the cost of a discrete decrease in paCO2 (non-significant difference), relevant increase in bicarbonatemia and chloremia decrease to values similar to those of $\mathrm{T} 2$, both were statistically significant differences from T3 to T4. Despite of the significant decrease in calcemia in T3, the mean value was above inferior limit of normality for rabbits which is 5.84 at $14.4 \mathrm{mg} / \mathrm{dl}$. At time T4 there was significant serum phosphorus and magnesemia decrease.

\section{GS Group}

AttimeT3, glycerin solution resulted inhyperchloremic metabolic acidosis, which was completely compensated in time T4. A hyperchloremic acidosis was probably due to fecal loss of bicarbonate, also associated to sodium and potassium loss. At time T4, the mean value of natremia 
presented an approximate deficit of $4.8 \mathrm{mEq}$ in relation to time $\mathrm{T} 2$, immediately before enema, a statistically significant difference. Such $\mathrm{Na}$ deficit was not followed by weight loss or significant hematocrit decrease; thus, it represents more of a $\mathrm{Na}$ fecal loss than a hemodilution resulting form a free water excess. In spite of the significant calcemia decrease in $\mathrm{T} 2$, the mean value was above lower normality limit for rabbits, which is 5.84 at $14.4 \mathrm{mg} / \mathrm{dl}$. At time T4 there was a significant serum phosphorus and magnesemia decrease.

\section{SPS Group}

At time T3 there was a metabolic acidosis with high anion gap and hypernatremic dehydration. At time T4, the animals progressed by normalizing $\mathrm{pH}$ mean values, bicarbonate, $\mathrm{paCO} 2$, base excess and weight in relation to time T1. However, in relation to time T2, time T4 values, still pointed to a significant increase in arterial bicarbonate and significant weight loss, meaning that metabolic acidosis and hypernatremic dehydration caused by the sodium phosphate solution, in the first four hours after enema, progressed to a metabolic alkalosis in 24 hours, and recovery was only partial concerning weight loss and paCO2 values normalization, natremia, chloremia and kalemia. At time T3, a significant hypocalcemia was observed; non significant increase of mean serum phosphorus and significant hypomagnesemia. Indeed, mean calcemia was statistically lower for this group than for PEG, ISS and GS groups (time T3) and magnesemia mean value statistically lower than GS group (time T3) and ISS group (time T4). At time T4 calcemia level was normalized, but magnesemia mean value was not. No rabbit had renal insufficiency, according to blood creatinine mean values, which may be due to the fact of all rabbits being young.

\section{Discussion}

The rabbit was chosen for this study because of its distinguished cecal appendix, compared to most animals which are usually used in experiments. The aim of the present study was to assess water, electrolyte and acid-base balances alterations caused by several solutions which are already used at the clinic for antegrade enema purposes. It did not assess efficiency or time required for intestinal cleansing of the colon. All animals had diarrhea (liquid and clear feces) between times T2 and T3. Despite of the mechanical cleansing of all colon had not been confirmed, it was clinically concluded that colons were emptied of fecal matter. The solutions assessed by the present study are used as laxatives in intestinal obstipation treatment or intestinal preparation prior to operation, radiology exam and colonoscopy. Posologies and directions are limited to via oral, nasogastric and rectal tubes; and Brazilian pharmacies provide no directions concerning or a study to set minimal or maximal doses of the antegrade colonic enema, in humans or animals. A literature review showed that dosage has not been defined for any of the solutions used in antegrade enemas; they are adjusted by trial and error for each patient individually. Administered doses vary from patient to patient taking part in the study. Some authors described that patients require varied solutions, at different volumes and intervals ${ }^{3,11,14}$. Obtained doses for each one of the solutions were tested in the pilot-project, caused liquid and clear diarrhea, were well tolerated and caused discrete abdominal distention in rabbits. Most of them showed no other clinical sign besides diarrhea. Day 6 postop was chosen for enema, because it could be affirmed for sure that normal peristaltic movements were already present and also avoided stoma stenosis. Technical difficulty in keeping a catheter shaping the stoma in the rabbit could result in stenosis. Many studies refer to complications related to the use of antegrade enemas and in a retrospective study, these complications outnumbered the operation ones16. Nevertheless, in most articles only the clinical manifestations are described and metabolic assessments were only carried out in more severe cases $^{8,10,11,12}$. Water and electrolyte absorption are closely related to colon surface area which is in contact with the enema, solution volume and the duration of the enema retention. Therefore, patients with anal stenosis, dismotility or colon dilatation, due to congenital or acquired megacolon, are more susceptible to metabolic complications of enema administration. Although these complications risks may seem low, the potential morbidity of these cases point to the need of checking on electrolytes regularly ${ }^{12}$. The polyethylene glycol electrolyte solution has not been related in literature, to water, electrolyte or acid-base balances disturbances or collateral symptoms. A possible inconvenience could be the need of administering a great volume, resulting in a high quantity of residues on account of the osmotic gradient of polyethylene glycol ${ }^{14}$. Large water volumes for ACE procedures have been frequently used for being simple and without complications to most of the patients ${ }^{15}$, however intoxication with water retention and excessive absorption, resulting in hyponatremia have been reported by some authors ${ }^{2,7}$. Although electrolyte alterations are rare, the potential morbidity of these patients demands constant regular evaluation ${ }^{12}$. Isotonic saline solution is one of the most used solutions. In order to cut down on costs, $\mathrm{NaCl}$ is empirically added to the water at home and the measure used is the spoon, which can either be more or less full or differ in size. Most complications are related to hypertonic saline solution. The use of water and saline solution in various concentrations was reported for the antegrade enema in children, with several complications, including convulsive crisis associated with electrolyte disturbances, without specifying the solution concentration ${ }^{10}$. An intoxication case 15 months after the operation with hypertonic saline solution enema showed hyperchloremic and hypernatremic metabolic acidosis ${ }^{5}$. The only fatal case reported in literature was of an infant 
with VATER association, after a homemade hypertonic saline solution enema on 5th month postop. A child went into coma due to hyperchloremic and hypernatremic metabolic acidosis ${ }^{4}$. These complications may be aggravated by some conditions, such as dehydration, renal insufficiency, especially when associated to tubular renal dysfunction and to central nervous system diseases which alter responses to thirst. The glycerin solution at $50 \%$ has been used combined with water or with saline solution ${ }^{16}$. Its osmotic power is efficient with low volumes and has not been related to complications. Acidosis was probably caused by fecal loss of $\mathrm{HCO} 3$, and also $\mathrm{Na}$ and $\mathrm{K}$ losses. These findings suggest that not intense metabolic effects are quickly compensated by the organism. Sodium phosphate solution antegrade enema is one of the most used solutions. Its isolated usage or associated to a saline solution has been supported for its efficiency and the low volume required for achieving colonic cleansing which provides continence, especially in the most difficult cases ${ }^{17}$. The most frequent complication is abdominal colic ${ }^{9}$. Other clinical manifestations include vomiting, nauseas and dizziness have been managed by lowering dose, infusion speed or dilution of sodium phosphate solution and the use of antispasmodics before enema ${ }^{3,9}$. Intoxication with phosphate was reported due to dose repetition, since the initial dose did not result in rectal excretion of enema within 1 to 2 hours9. Malone, Curry and Osborne reported no signs, symptoms or hydroelectrolyte disturbances, but they suggest that patients should wait for one hour and then proceed irrigation with saline solution; and only if, in doing so, they cannot evacuate they should admitted3. No deaths were related to sodium phosphate solution antegrade enema in literature. However there are reports of severe complications (hyperphosphatemia, hypocalcemia, hypomagnesemia, dehydration and metabolic acidosis) and deaths related to the use of this solution via oral, nasogastric and rectal tubes, in obstipation treatments in children6. Most of the iatrogenic complications reported in literature are related to the use of this solution and in some cases they were due to excessive volume. Contraindications of sodium phosphate solution are for patients in co-morbid conditions which affect physiological compensation mechanisms responsible for keeping intravascular volume, and for improving hyperphosphatemia and consequent hypocalcemia. It is also inadvisable for patients with inadequate hydration risk (diarrhea, restrictive oral ingestion), sub-clinical renal insufficiency (elderly patients and those with a decreased glomerular filtration rate), known electrolyte disturbances, malabsorption and proximal and distal gastrointestinal tract motility alterations19. Renal insufficiency and volume depletion are responsible for a decreased renal excretion of phosphate and increase hyperphosphatemia. On the other hand, such hyperphosphatemia causes a decline in Ca concentration. A severe hypertonic dehydration can result in acute renal insufficiency and it is likely to happen due to $\mathrm{Na}$ absorption mechanism and water loss in the colon. Enema regimens need to be improved so that besides immediate efficiency of the colonic emptying, it may cause the least metabolic effects and discomfort, especially to patients suffering from intestinal dismotility, renal insufficiency, congestive cardiopathies and other pathologies. Patients treated with chronic enemas administrations, particularly those suffering from chronic colon dilatation due to an obstructive disease, are highly susceptible to metabolic complications, as well as children who are younger than four years old. This data suggests that, as enemas may have immediate metabolic effects, in relation to the frequency of enema administration, it must be observed whether they are cumulative in the long run. Stomas construction in the sigmoid colon for antegrade enema purposes is an option for cecum access, which may shorten enema time administration and quantity of solution required, making irrigation route shorter. References made to the use of this technique in specific cases, particularly for patients with long transit times are optimistic, but despite of the fact that it can lower both risks and complications resulting from the enema, it has been performed in few patients20,21. The antegrade enema has been used in children aged 18 months onwards, however adhesion to treatment is difficult. Therefore it is suggested that stoma constructions for ACE procedures should not be made before the age of five. This would lower risks of intoxication with solutions22,23. Patients who face difficulties in expelling enema or who present inexplicable symptoms, for no apparent reason, such as lethargy, vomiting or tetany, should go through a differential diagnosis with hydroelectrolyte disturbs associated to the enema. Further research is still called for, especially concerning enema regimens, its effects on colon mucosa in the long term and the search for a solution or a combination of solutions of similar or better tolerance, and with less occurrences of complications than what was described and a more universal administration so as to make ongoing basis use of continent antegrade enema safer.

\section{Conclusions}

All solutions used in this study caused minor alterations on water, electrolyte or acid-base balances. The most intense ones were caused by hypertonic sodium phosphate solution (SPS) and isotonic saline solution (ISS) and the least by polyethylene glycol electrolyte solution (PEG) and glycerin solution 12\% (GS).

\section{References}

1. Malone PS, Ransley PG, Kiely EM. Preliminary report: the antegrade continence enema. Lancet. 1990;336:1217-8.

2. Aksnes G, Diseth TH, Helseth A, Edwin B, Stange M, Aafos G, Emblem R. Appendicostomy for antegrade 
enema: effects on somatic and psychosocial functioning in children with myelomeningocele. Pediatrics. 2002;109:484-9.

3. Malone PSJ, Curry JI, Osborne A. The antegrade continence enema procedure why, when and how? World J Urol. 1998;16:274-8.

4. Schreiber CK, StoneAR. Fatal hypernatremia associated with the antegrade continence enema procedure. J Urol. 1999;162:1433-4.

5. Goepel M, SPerling H, Stöhrer M, Otto T, Rübben H. Management of neurogenic fecal incontinence in myelodysplastic children by a modified continent appendiceal stoma and antegrade colonic enema. Urology. 1997;49:758-61.

6. Hunter MF, Ashton MR, Griffiths DM, Ilangovan P, Roberts JP, Walker V. Hyperphosphataemia after enemas in childhood: prevention and treatment. Arch Dis Child. 1993;68:223-4.

7. Meier DE, Foster ME, Guzzetta PC, Coln D. Antegrade continent enema management of chronic fecal incontinenceinchildren.JPediatrSurg. 1998;33:1149-52.

8. Gerharz EW, Vik V, Webb G, Leaver R, Shah PJR, Woodhouse CRJ. The value of the MACE (Malone antegrade colonic enema) procedure in adult patients. J Am Coll Surg. 1997;185:544-7.

9. Curry JI, Osborne A, Malone PS. How to achieve a successful Malone antegrade continence enema. J Pediatr Surg. 1998;33:138-41.

10. Ekmark E, Adams RC. The antegrade continence enema (ACE) surgical procedure: patient selection, outcomes, long-term patient management. Eur J Pediatr Surg. 2000;10(suppl I):49-51.

11. Marshall J, Hutson JM, Anticich N, Stanton MP. Antegrade continence enemas in the treatment of slowtransit constipation. J Pediatr Surg. 2001;36:1227-30.

12. Yerkes EB, Rink RC, King S, Cain MP, Kaefer M, Casale AJ. Tap water and the Malone antegrade continence enema: a safe combination? J Urol. 2001;166:1476-8.
13. Esteves E, Martins JL. Estudio comparativo experimental entre apendicostomías con y sin plicatura del ciego en conejos. Rev Cir Infant. 1998;8:218-25.

14. Dick AC, McCallion WA, Brown S, Boston VE. Antegrade colonic enemas. Br J Surg. 1996;83:642-3.

15. Koyle MA, Kaji DM, Duque M, Wild J, Galansky SH. The Malone antegrade continence enema for neurogenic and structural fecal incontinence and constipation. J Urol. 1995;154(2 Pt 2):759-61.

16. Youssef NN, Barksdale Jr E, Griffiths JM, Flores AF, Di Lorenzo C. Management of intractable constipation with antegrade enemas in neurologically intact children. J. Pediatr Gatroenterol Nutr. 2002;34:402-5.

17. Hensle TW, Reiley EA, Chang DT. The Malone antegrade continence enema procedure in the management of patients with spina bifida. J Am Coll Surg. 1998;186:669-74.

18. Graf JL, Strear C, Bratton B, Housley HT, Jennings RW, Harrison MR, Albanese CT. The antegrade continence enema procedure: a review of the literature. J Pediatr Surg. 1998;33:1294-6.

19. Hookey LC, DePew WT, Vanner S. The safety profile of oral sodium phosphate for colonic cleansing before colonoscopy in adults. Gastrointest Endosc. 2002;56:895-902.

20. Gauderer MWL, DeCou JM, Boyle JT. Sigmoid irrigation tube for the management of chronic evacuation disorders. J Pediatr Surg. 2002;37:348-51.

21. Liloku RB, Mure PY, Braga L, Basset T, Mouriquand PD. The left Monti-Malone procedure: preliminary results in seven cases. J Pediatr Surg. 2002;37:228-31.

22. Griffiths DM, Malone PS. The Malone antegrade continence enema. J Pediatr Surg. 1995;30:68-71.

23. Mor Y, Quinn FMJ, Carr B, Mouriquand PD, Duffy PG, Ransley PG. Combined Mitrofanoff and antegrade continence enema procedures for urinary and fecal incontinence. J Urol. 1997;158:192-5.

\section{Correspondence:}

Laura Helman

Rua da Passagem, 75/202 B1 1

22290-030 Rio de Janeiro - RJ Brazil

Phone: (55 21)2295-4251 / 87870121

helman@ufu.br
Conflict of interest: none Financial source: CAPES

Received: March 12, 2007

Review: May 14, 2007

Accepted: June 12, 2007

\section{How to cite this article}

Helman L, Martins JL, Fagundes DJ, Esteves E, Lima CP, Costa AS. Experimental antegrade enema. Effects on water, electrolyte and acid-base balances with different solutions. Acta Cir Bras. [serial on the Internet] 2007 Sept-Oct;22(5). Available from URL: http://www.scielo.br/acb 